\title{
Design of Blended Learning Based on Tri Kaya Parisudha Using Kelase Platform in Realizing Hybrid-Superitem Learning in Mathematics Lessons
}

\section{Putu Wisna Ariawan}

Department of Mathematics Education, Universitas Pendidikan Ganesha, Indonesia, wisna.ariawan@undiksha.ac.id

\section{Dewa Gede Hendra Divayana}

Department of Information Technology Education, Universitas Pendidikan Ganesha, Indonesia, hendra.divayana@undiksha.ac.id

This study aimed to develop the blended learning design using the Kelase platform with learning concepts that internalize the Tri Kaya Parisudha concept and the Mathematics material structure by using Superitem concept so that the Mathematics learning process at the level of high school or vocational can be more effective. This research was carried out with a development research approach using the Borg and Gall model with the main focus of development at the design development stage. Subjects involved in the development of the design were three researchers; the initial design trial was four experts and 30 Mathematics teachers. Data collection tools in the form of questionnaires, interview guidelines, and photo documentations. The technique used to analyze the data was quantitative descriptive. The results showed that the effectiveness of the blended learning design that had been developed was classified as good common with an average effectiveness percentage of $88.76 \%$. Based on that effectiveness percentage was compared to the five-scale categorization, it's recommended not to do a major revision of the blended learning design.

Keywords: blended learning, tri kaya parisudha, kelase platform, hybrid-superitem, mathematics lessons

\section{INTRODUCTION}

Mathematics is known as a difficult subject by students ranging from education at the elementary school level to high school or vocational. That difficulty is occured because students' thinking patterns are still not well structured in solving problems/cases given by the teacher while studying Mathematics (Ersoy, 2016: 85); (Aminudin, et al., 2019: 9). Steps that can be taken to train a mindset to be more structured and critical in

Citation: Ariawan, I. P. W., \& Divayana, D. G. H. (2020). Design of Blended Learning Based on Tri Kaya Parisudha Using Kelase Platform in Realizing Hybrid-Superitem Learning in Mathematics Lessons. International Journal of Instruction, 13(3), 679-698. https://doi.org/10.29333/iji.2020.13346a 
answering the Mathematics cases is to learn and answer Mathematical questions starting from the easiest to the hardest levels.

In the era of industrial revolution 4.0 as it is today, hybrid learning has begun to emerge by applying blended learning models that are supported by free platforms and applications from the internet so that it can be used as supporting media in Mathematics lessons to improve students' cognitive abilities. Wichian and Thanongsak (2019: 12) and Suyasa, et al. (2018: 6204), in principle stated that the blended learning model provides content and questions with levels of difficulty ranging from low levels to the most challenging levels. It was done to train students' cognitive abilities in understanding Mathematics or other lessons independently outside the classroom or together when meeting face to face with the teacher in classroom.

However, the learning process that is expected to occur in the era of industrial revolution 4.0 is not merely to produce students with high abilities in the cognitive domain only, but also students' abilities in the affective and psychomotor domains. Students' abilities in the cognitive domain are expected can be measured through their ability to answer multiple-choice tests correctly. The students' abilities in the affective domain are expected can be measured from the students' speech in discussing and expressing opinions when learning process using blended learning. The students' abilities in the psychomotor domain are expected can be measured by the speed and accuracy of students in answering the essay tests correctly and quickly. To answer that expectation it is necessary to develop a blended learning model using a free application platform from the internet with material content and the learning process that is adopting local wisdom so that it can make quality Mathematics learning refers to the cognitive, affective, and psychomotor domains.

The right learning model was developed as an innovation to solve existing problems, namely in the form of blended learning using the Kelase platform with its learning process based on Tri Kaya Parisudha and the material content structure in stages that adopted the concept of Superitem. Based on the facts and innovations initiated, the problem statement in this research was "How was the effectiveness level of blended learning design that developed using the Tri Kaya Parisudha-based Kelase platform and adopting the concept of Superitem in realizing Hybrid-Superitem learning for Mathematics learning at the high school/vocational level?"

\section{LITERATURE REVIEW}

This research was motivated by research conducted in 2018 by Suanthara (2018: 139) about "the influence of Tri Kaya Parisudha learning model on the learning achievement of V semester students of the Hinduism education department at STKIP Agama Hindu Singaraja in the academic year 2016/2017". Where that results of Suanthara's research have revealed the concept of learning based on the Tri Kaya Parisudha concept that can make the learning process conducive and well-controlled so that it can encourage students to actively think, talk and do something was in accordance with teaching materials more optimally. Constraints found in Suanthara's research was did not have a detailed explanation of the material related to the values contained in the Tri Kaya 
Parisudha concept (Manacika, Wacika, and Kayika) used in the learning process to find optimal learning outcomes in the cognitive domain through Manacika, the affective domain through Wacika, and the psychomotor domain through Kayika.

Other studies that also underlie this study include Eryilmaz (2015: 255) showed that the learning process with blended learning models is more effective than the learning process with face-to-face models in the classroom. This is because the blended learning model is designed in the form of an online system so the learning process can take place anywhere and easily conduct material sharing, easily conduct discussions through forums, easily carry out tests/problem exercises, the material can be packaged in the form of images, texts, and summaries which is equipped with video. The limitation that was found in Eryilmaz's research was the lack of material content and examples of practice questions that are packaged in stages ranging from the easiest to the most difficult levels.

The research conducted by Jamil (2018:19) showed the importance of utilization the Superitem concept in assessing the critical thinking ability of students in solving problems/cases in the process of learning Mathematics (especially related Algebra) so that they can know more about the cognitive abilities of students in learning Algebraic material. The constraints in Jamil's research was not being able to demonstrate students' abilities in the affective, cognitive, and psychomotor domains in solving the Algebraic problems.

The research conducted by Supandi, Kusumaningsih, and Ariyanto (2014: 53) showed that blended learning can create an interesting and creative learning climate where students can find learning resources independently through the internet to support the material obtained in the classroom, so can further improve skills and student knowledge in solving mathematical problems directly and independently. The limitation of Supandi, Kusumaningsih, and Ariyanto's research was it had not be explained about elements that are needed in blended learning to can trigger students' affective abilities in the Mathematics learning process.

The research conducted by Wijanayu, Hardyanto, and Isnaeni (2018: 89) showed similarities with this research in terms of the use of free applications on the internet that are equally appropriate used to realize the blended learning model that support the learning process. Research conducted by Suana et al. (2017: 176) showed blended learning for basic physics subjects facilitated using schoology to improve understanding of concepts (cognitive) and students' psychomotor skills in solving problems/cases in the learning process the basic physics. Constraints that have been found in research conducted by Suana et al. was the difficulties of students in writing answers in the form of symbols, graphs, and mathematical equations in the discussion forums provided by schoology. Besides, not all students are active and consistently follow the learning process through the discussion forums that have been provided. Research conducted by Jubhari et al. (2016: 91) showed that the value of local wisdom in the form of respect for parents and mutual cooperation can affect the learning process students, especially in the affective and psychomotor domains. Constraints that have been found in research conducted by Jubhari et al. was the inhibition of students' ability to express their ideas 
because of the element of shame with older people, so that their cognitive abilities do not increase.

Permatasari's research (2014: 136) showed that learning outcomes for students taught with Superitem learning models are better than students taught without learning models Superitem, because with Superitem students can learn Mathematical material with structured patterns ranging from simple levels to the most complex levels. The limitation that still appears in Permatasari's research was that it had not been able to show an increase in the Mathematics learning process in the affective domain, because in the learning process using the superimposed model in the study only focuses on the cognitive and psychomotor domains.

The research conducted by Albiladi and Alshareef (2019: 232) showed that blended learning is an innovative media that is very well used in the process of teaching English because students feel comfortable in learning with the facilities that make it easier for teachers to monitor and interact with students both online through the internet and offline through face-to-face classes. Besides, the presence of blended learning makes it easy for students to develop their thinking knowledge, develop their communication skills and their skills in operating computers. The limitation in Albiladi and Alshareef's research was it had not been fully explained about the content of English materials contained in blended learning with structured arrangements ranging from low complexity to high complexity. Research conducted by Utami, Santyasa, and Suswandi (2018: 1) showed that students' mastery of the concept of physics in the learning process that utilizes blended learning was higher than student mastery towards physics concepts that do not utilize blended learning. This occurred because blended learning provides convenience facilities for students to access and explore information related to the physics material they are learning from various sources both independently through the internet and joint discussions through online discussions and direct discussions during in class meetings. The limitation that was found in Utami, Santyasa, and Suswandi's research was there had not been an in-depth discussion about the mechanism of blended learning that can be used to measure learning outcomes in physics lessons that refer to the affective domain.

\section{METHOD}

The blended learning design in this study used the development model of Borg and Gall, which consists of 10 stages (Hendikawati, Zahid, and Arifudin, 2019: 392). The details of those ten stages can be seen in Figure 1. 


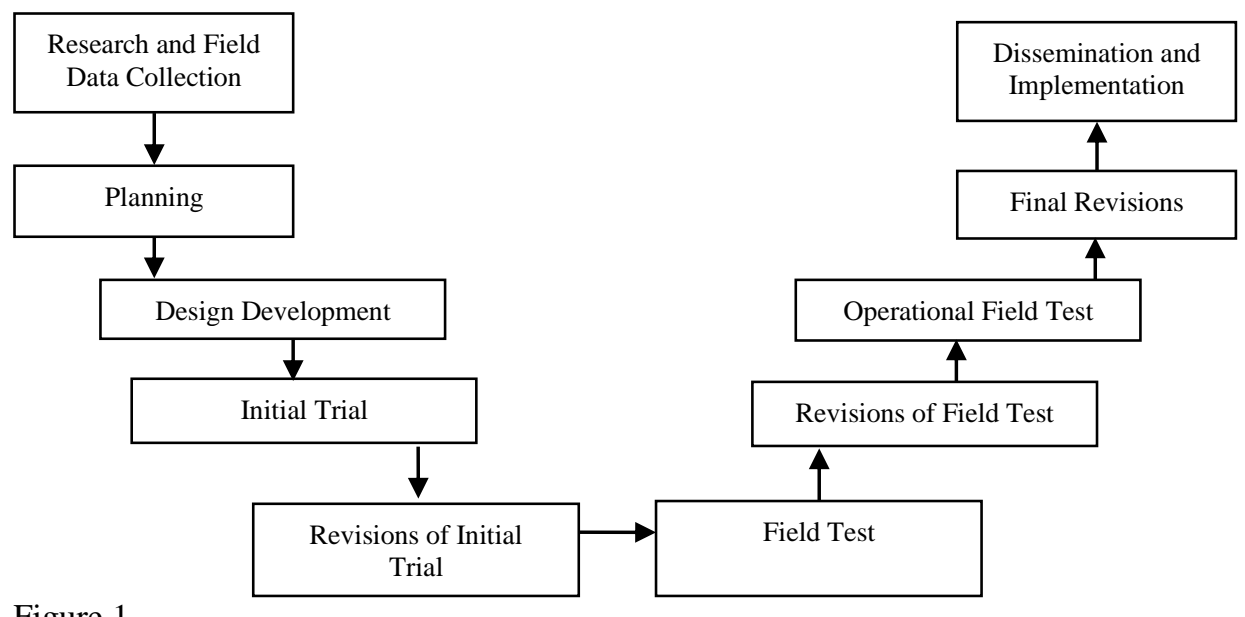

Figure 1

Ten Stages of Borg \& Gall Model

However, specifically in the study of this year only focused on several stages, including: (1) research and field data collection, (2) planning; (3) design development, (4) initial trials, and (5) revisions of initial trials. Subjects involved in the field data collection were four field workers, subjects involved in the design and development of the design as many as three people consisting of researchers, subjects involved in the initial trial involved two education experts, two informatics experts, and 30 teachers in high school/vocational school that spread across six regencies in the province of Bali (Gianyar, Buleleng, Tabanan, Badung, Klungkung, and Denpasar).

The instruments that were used in the initial data collection in the field were interview guides and documentation photos. The instruments that were used in conducting the initial trial of the blended learning design that was formed was a questionnaire consisting of 15 items in question. The measurement of instrument validity in the form of interview guidelines and questionnaires was carried out by content validation testing of the instrument by two experts, such as a mathematics education expert and an informatics education expert. The formula was used to measure the level of instrument content validation used the Gregory formula.

The results of field data collection were then processed and analyzed using quantitative descriptive techniques. The reason for using this analysis technique is to make it easier for researchers to interpret the results of quantitative calculations into a narrative form so that later it will be easier for decision making/conclusions. Conclusion of the results of the analysis was done by interpreting the percentage descriptive calculation score into categorization which refers to the five-scale categorization standard so that later the categorization results can be used as a basis for following up on the blended learning design. The formula used to determine the percentage descriptive calculation in full can be seen in equation (1) (Ariawan et al., 2018: 6582), while the five-scale categorization standard can be seen in Table 1 (Ariawan et al., 2018: 6583). 


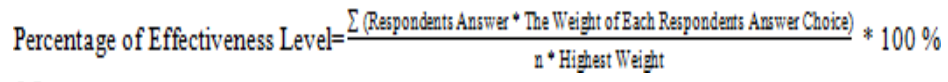

Notes:

$\sum=$ Total

$\mathrm{n}=$ Total of all questionnaire items

Table 1

The Standard of Five Scale Catagorization

\begin{tabular}{lll}
\hline Percentage Range & Category & Recommendation \\
\hline $90-100 \%$ & Very Good & No Revision Needed \\
$80-89 \%$ & Good & No Revision Needed \\
$65-79 \%$ & Enough & Revision \\
$55-64 \%$ & Less & Revision \\
$0-54 \%$ & Very Less & Revision \\
\hline
\end{tabular}

\section{FINDINGS AND DISCUSSION}

This study shows results that focus on several stages of development. The full information about the results intended can be explained as follows.

a. Results at the research stage and field data collection

At this stage, data were obtained on material topics taught in high school/vocational schools that refer to the 2013 curriculum based on the regulation of the Minister of Education and Culture of the Republic of Indonesia number 24 of 2016, including:

1) Class $X$, which consists of: (a) The Equations and Inequalities' Linear of Absolute Value for One Variable, (b) Linear Equation System of Three Variable, (c) Functions, and (d) Trigonometry.

2) Class XI, which consists of: (a) Mathematical Induction, (b) Linear Program, (c) Matrix, (d) Transformation, (e) Sequence, (f) Limit Function, (g) Derivatives, and (h) Integral.

3) Class XII, which consists of: (a) Three Dimensions, (b) Statistics, (c) Probability, (d) Coherence and Congruence.

Besides obtaining data on the topic of Mathematics material, at this stage also needed the Tri Kaya Parisudha concept for internalized in the online learning process. Therefore, on the Kelase platform, we must demonstrate the use of the Tri Kaya Parisudha concept in the learning process by providing several forms, including forms of Manacika-based material, forms of Wacika-based material, and forms of Kayikabased material. All those forms formed based on the matrix of the relationship between the topic of Mathematics material that adopted the Superitem structure with the Tri Kaya Parisudha concept. The detailed of that matrix display can be seen in Figure 2. 


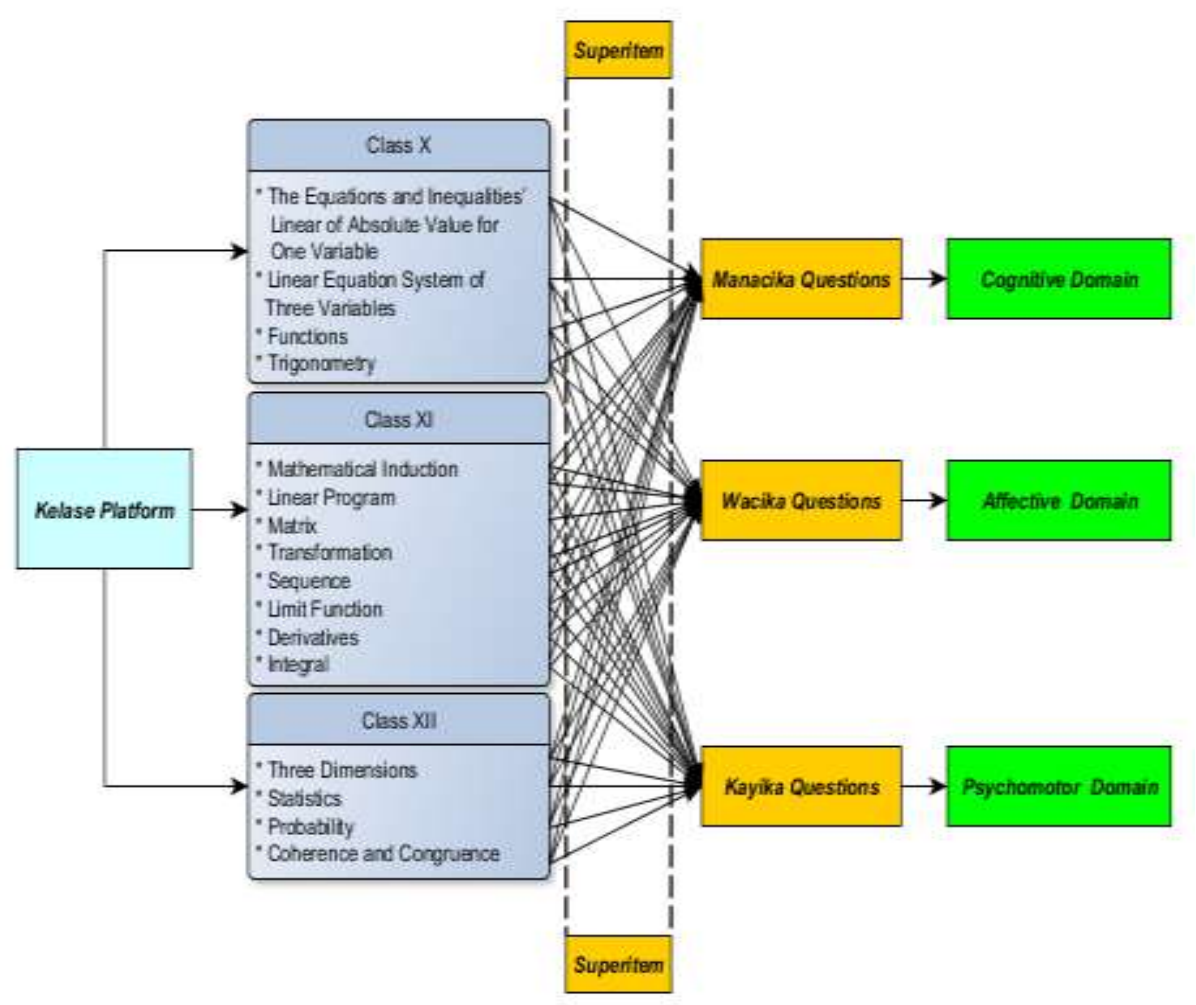

Figure 2

Matrix of Relationship between Mathematics Topics that Adopted the Superitem with Tri Kaya Parisudha in Blended Learning using Kelase Platform

Figure 2 shows the blended learning that made with the Kelase platform consisting of several topics of Mathematics material from class X to class XII. Each topic of the materials has several questions that are packaged with difficulty levels based on the Superitem concept, namely from the lowest to the most serious difficulty. Besides that, the questions are also packaged into three domains that determine learning results by adopting the Tri Kaya Parisudha concept, including Manacika questions, Wacika questions, and Kayika questions. Manacika questions are used to measure learning outcomes in the cognitive domain, Wacika questions to measure affective domains, and Kayika questions to measure psychomotor domains.

b. Results at the planning stage

At this stage was obtained data about time, resources and activities carried out in realizing the blended learning design that was created using the Tri Kaya Parisudhabased Kelase platform with content material that adopted the concept of Superitem. The details of the data intended at the planning stage can be seen in Table 2 . 
Table 2

Data About Activity Details, Time, and Human Resources, Required in Making Blended Learning Design

\begin{tabular}{lll}
\hline Activity & Time & Human Resources \\
\hline $\begin{array}{l}\text { Determination of Material Content for Class X, XI, and XII } \\
\text { Arrangement of material content from the lowest to the }\end{array}$ & 2 days & 3 persons \\
$\begin{array}{l}\text { highest difficulty level } \\
\text { Arrangement of Forms of Assignment and Process }\end{array}$ & 3 persons \\
$\begin{array}{l}\text { Discussions in learning based on Tri Kaya Parisudha } \\
\text { The blended learning design uses the Kelase platform }\end{array}$ & 2 days & 3 persons \\
\hline
\end{tabular}

c. Results at the stage of design development

At this stage, the Tri Kaya Parisudha based blended learning design was created with the Kelase platform and material content that adopted the concept of Superitem so that it can realize Hybrid-Superitem learning for Mathematics lessons in class X, XI, and XII at the high school/vocational level in Bali Province. The form of blended learning design intended can be seen fully in Figure 3.

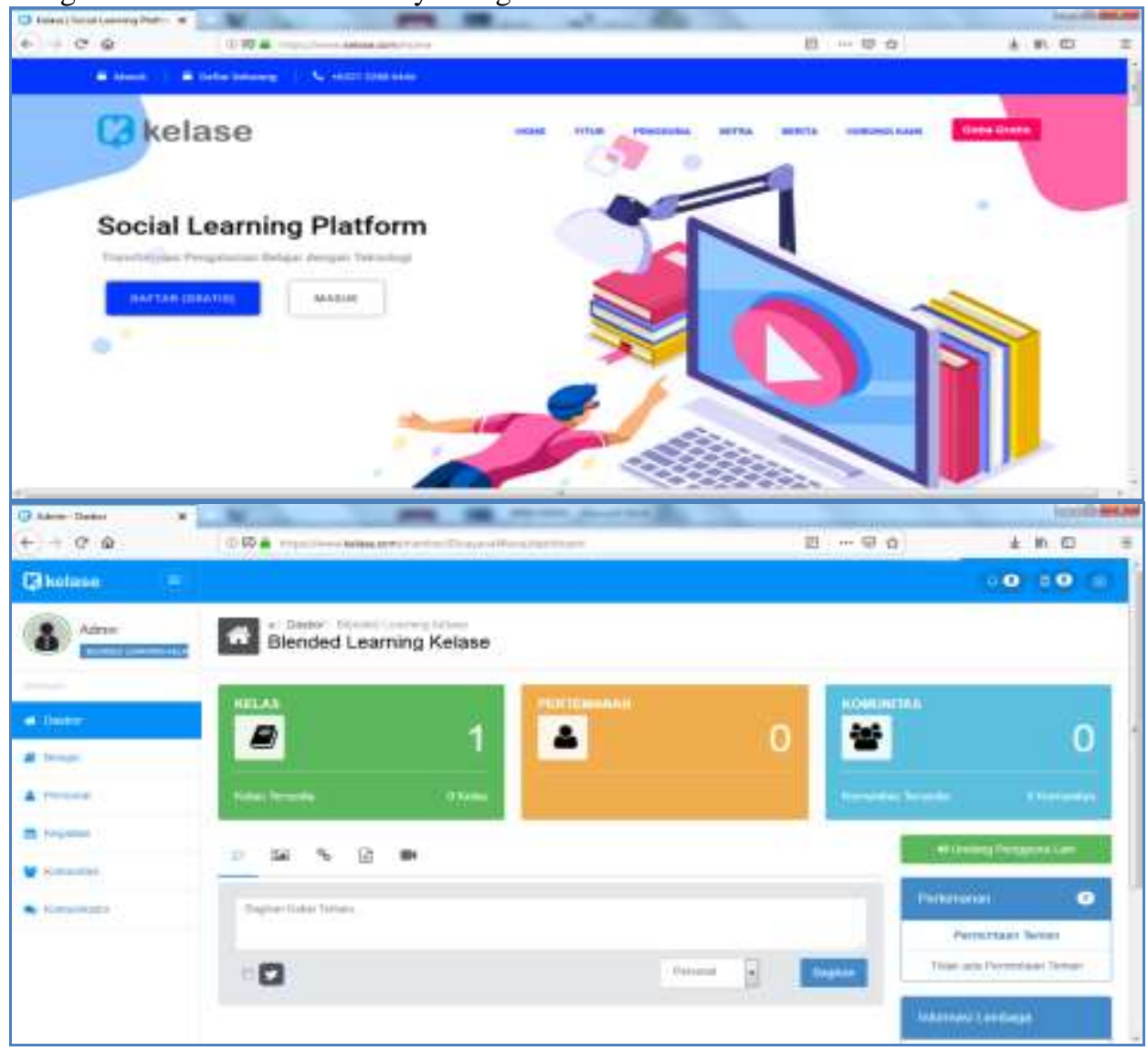

International Journal of Instruction, July $2020 \bullet$ Vol.13, No.3 


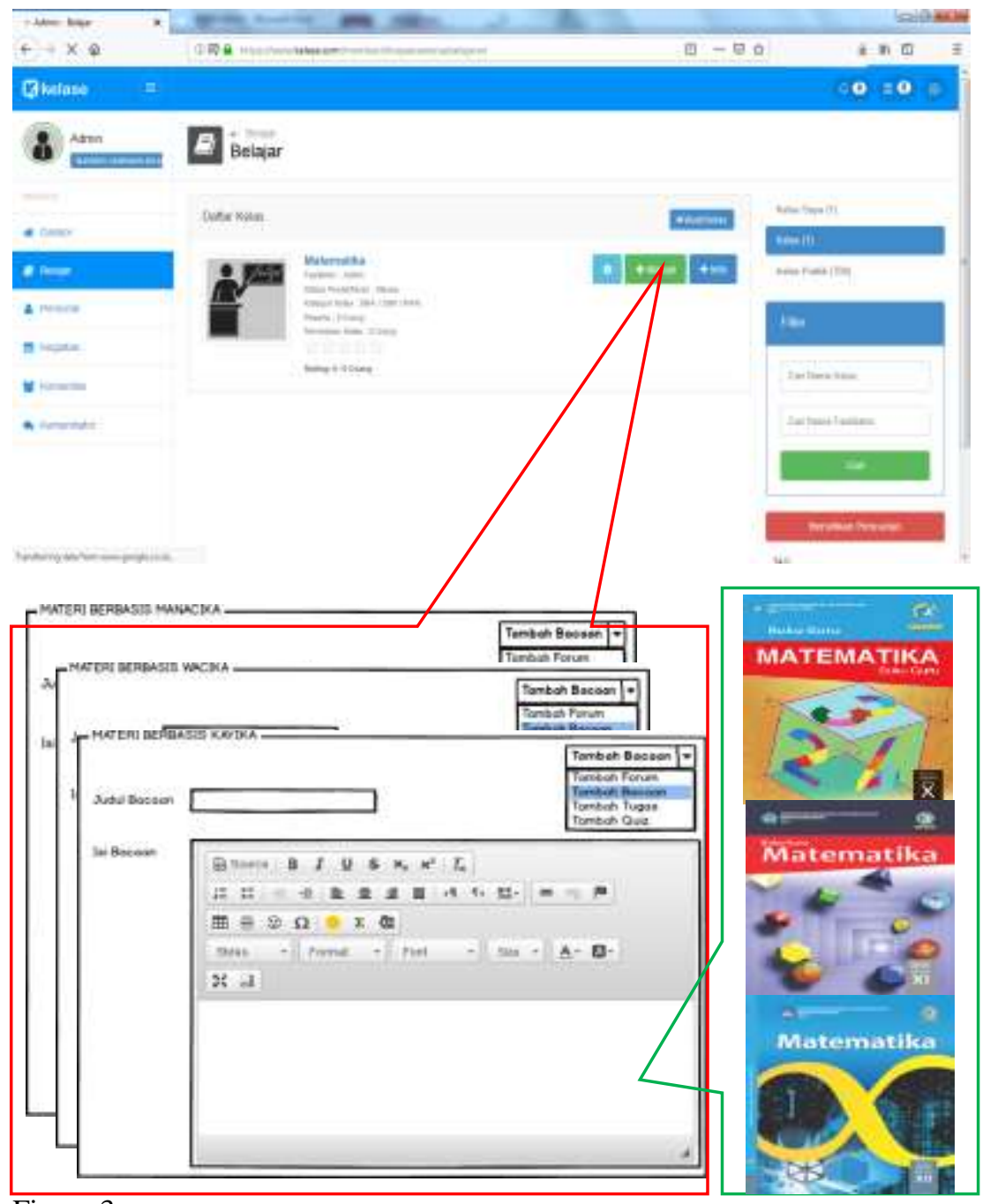

Figure 3

Blended Learning Design Based on Tri Kaya Parisudha Uses Kelase Platform with Content Material that Adopts the Superitem Concept

d. Results at the initial trial stage

At this stage, data obtained from the initial trial results on the blended learning design that has been formed. The initial trial was conducted by 34 people consisting of 30 Mathematics teachers from several high schools/vocational schools spread across six regencies in Bali Province, two education experts, and two informatics experts. The data from the initial trial results can be seen fully in Table 3 . 
Table 3

Initial Trial Results of Tri Kaya Parisudha-Based Blended Learning Design that Created Using the Kelase Platform and Adoption of the Superitem Concept

\begin{tabular}{|c|c|c|c|c|c|c|c|c|c|c|c|c|c|c|c|c|c|c|c|c|c|c|}
\hline \multirow{2}{*}{ Respondents } & \multicolumn{20}{|c|}{ Items- } & \multirow[b]{2}{*}{$\Sigma$} & \multirow{2}{*}{$\begin{array}{l}\text { Effectiveness } \\
\text { Percentage } \\
(\%)\end{array}$} \\
\hline & 1 & 2 & 3 & 4 & 5 & 6 & 7 & 8 & 91 & $\begin{array}{lll}0 & 1\end{array}$ & 112 & 213 & 314 & 415 & & $16 \mathrm{~L}^{7}$ & & 8 & $9 ?$ & 20 & & \\
\hline Expert-1 & 5 & 5 & 5 & 4 & 5 & 4 & 5 & 5 & 4 & 5 & 4 & 5 & 5 & 4 & 5 & 4 & 4 & 5 & 4 & 4 & 91 & 91.00 \\
\hline Expert-2 & 5 & 5 & 4 & 4 & 4 & 5 & 4 & 5 & 4 & 4 & 5 & 4 & 5 & 4 & 4 & 4 & 5 & 5 & 5 & 4 & 89 & 89.00 \\
\hline Expert-3 & 4 & 5 & 5 & 4 & 5 & 4 & 5 & 4 & 5 & 5 & 5 & 5 & 5 & 4 & 5 & 5 & 4 & 5 & 4 & 5 & 93 & 93.00 \\
\hline Expert-4 & 5 & 5 & 5 & 4 & 5 & 4 & 4 & 4 & 5 & 5 & 5 & 4 & 5 & 5 & 4 & 4 & 4 & 4 & 4 & 4 & 89 & 89.00 \\
\hline Teacher-1 & 5 & 5 & 4 & 5 & 3 & 4 & 5 & 4 & 5 & 4 & 5 & 4 & 5 & 4 & 5 & 4 & 4 & 5 & 4 & 4 & 88 & 88.00 \\
\hline Teacher-2 & 4 & 5 & 5 & 4 & 4 & 4 & 4 & 4 & 4 & 4 & 5 & 4 & 4 & 5 & 4 & 4 & 4 & 5 & 5 & 5 & 87 & 87.00 \\
\hline Teacher-3 & 5 & 4 & 5 & 4 & 4 & 5 & 4 & 5 & 5 & 4 & 5 & 4 & 5 & 4 & 4 & 4 & 5 & 5 & 4 & 4 & 89 & 89.00 \\
\hline Teacher-4 & 4 & 5 & 5 & 4 & 5 & 5 & 4 & 4 & 5 & 4 & 5 & 5 & 5 & 5 & 4 & 4 & 5 & 4 & 4 & 4 & 90 & 90.00 \\
\hline Teacher-5 & 5 & 5 & 4 & 4 & 4 & 4 & 5 & 5 & 5 & 4 & 5 & 4 & 5 & 4 & 5 & 4 & 5 & 4 & 4 & 5 & 90 & 90.00 \\
\hline Teacher-6 & 4 & 4 & 5 & 4 & 4 & 5 & 4 & 3 & 4 & 5 & 4 & 4 & 5 & 4 & 4 & 3 & 5 & 4 & 4 & 5 & 84 & 84.00 \\
\hline Teacher-7 & 5 & 5 & 5 & 4 & 5 & 4 & 4 & 4 & 5 & 4 & 4 & 5 & 5 & 4 & 5 & 4 & 5 & 4 & 5 & 5 & 91 & 91.00 \\
\hline Teacher-8 & 5 & 4 & 4 & 4 & 5 & 4 & 5 & 4 & 5 & 5 & 4 & 5 & 4 & 4 & 4 & 5 & 4 & 4 & 5 & 4 & 88 & 88.00 \\
\hline Teacher-9 & 5 & 5 & 5 & 4 & 4 & 4 & 4 & 5 & 4 & 4 & 5 & 4 & 4 & 4 & 5 & 5 & 5 & 5 & 5 & 4 & 90 & 90.00 \\
\hline Teacher-10 & 5 & 5 & 5 & 5 & 4 & 4 & 5 & 4 & 5 & 5 & 5 & 5 & 5 & 5 & 4 & 5 & 5 & 4 & 5 & 4 & 94 & 94.00 \\
\hline Teacher-11 & 5 & 4 & 5 & 4 & 3 & 4 & 4 & 5 & 3 & 4 & 4 & 4 & 4 & 4 & 5 & 4 & 5 & 4 & 4 & 4 & 83 & 83.00 \\
\hline Teacher-12 & 5 & 5 & 5 & 5 & 4 & 5 & 4 & 3 & 4 & 5 & 4 & 4 & 5 & 5 & 4 & 5 & 5 & 4 & 5 & 5 & 91 & 91.00 \\
\hline Teacher-13 & 5 & 5 & 5 & 4 & 4 & 3 & 4 & 4 & 5 & 4 & 4 & 4 & 4 & 4 & 5 & 3 & 5 & 5 & 4 & 5 & 86 & 86.00 \\
\hline Teacher-14 & 5 & 5 & 5 & 4 & 4 & 4 & 4 & 4 & 4 & 5 & 4 & 4 & 4 & 5 & 4 & 4 & 4 & 4 & 4 & 5 & 86 & 86.00 \\
\hline Teacher-15 & 5 & 4 & 5 & 3 & 5 & 3 & 5 & 5 & 5 & 5 & 4 & 4 & 5 & 4 & 4 & 4 & 5 & 5 & 5 & 4 & 89 & 89.00 \\
\hline Teacher-16 & 4 & 5 & 5 & 4 & 4 & 4 & 4 & 5 & 4 & 5 & 4 & 5 & 5 & 5 & 4 & 5 & 4 & 5 & 4 & 5 & 90 & 90.00 \\
\hline Teacher-17 & 5 & 4 & 4 & 4 & 5 & 4 & 4 & 5 & 4 & 5 & 5 & 4 & 5 & 4 & 5 & 4 & 4 & 5 & 4 & 5 & 89 & 89.00 \\
\hline Teacher-18 & 4 & 5 & 5 & 3 & 4 & 4 & 4 & 4 & 5 & 4 & 5 & 4 & 4 & 4 & 4 & 5 & 4 & 4 & 4 & 4 & 84 & 84.00 \\
\hline Teacher-19 & 5 & 4 & 5 & 4 & 4 & 3 & 5 & 4 & 4 & 4 & 5 & 4 & 5 & 5 & 5 & 5 & 5 & 5 & 4 & 5 & 90 & 90.00 \\
\hline Teacher-20 & 4 & 5 & 5 & 5 & 5 & 4 & 4 & 4 & 5 & 4 & 5 & 5 & 4 & 4 & 4 & 5 & 5 & 4 & 5 & 5 & 91 & 91.00 \\
\hline Teacher-21 & 4 & 5 & 4 & 4 & 5 & 4 & 5 & 5 & 4 & 4 & 5 & 4 & 5 & 5 & 5 & 4 & 4 & 4 & 4 & 5 & 89 & 89.00 \\
\hline Teacher-22 & 5 & 5 & 5 & 4 & 4 & 3 & 4 & 5 & 4 & 5 & 4 & 5 & 4 & 4 & 4 & 4 & 5 & 5 & 4 & 5 & 88 & 88.00 \\
\hline Teacher-23 & 5 & 4 & 4 & 4 & 4 & 5 & 4 & 4 & 5 & 4 & 5 & 5 & 5 & 5 & 4 & 3 & 4 & 5 & 4 & 5 & 88 & 88.00 \\
\hline Teacher-24 & 5 & 5 & 5 & 5 & 3 & 4 & 5 & 5 & 4 & 5 & 5 & 4 & 4 & 4 & 4 & 5 & 5 & 4 & 5 & 4 & 90 & 90.00 \\
\hline Teacher-25 & 4 & 5 & 4 & 4 & 4 & 5 & 4 & 4 & 4 & 4 & 4 & 4 & 5 & 5 & 5 & 4 & 4 & 5 & 4 & 5 & 87 & 87.00 \\
\hline Teacher-26 & 5 & 4 & 5 & 4 & 5 & 4 & 4 & 4 & 5 & 5 & 5 & 5 & 5 & 4 & 4 & 3 & 4 & 5 & 4 & 5 & 89 & 89.00 \\
\hline Teacher-27 & 4 & 5 & 5 & 3 & 4 & 5 & 4 & 5 & 4 & 4 & 4 & 4 & 4 & 5 & 5 & 4 & 5 & 4 & 4 & 5 & 87 & 87.00 \\
\hline Teacher-28 & 5 & 5 & 5 & 5 & 3 & 4 & 5 & 3 & 4 & 5 & 5 & 4 & 4 & 4 & 4 & 5 & 4 & 5 & 4 & 5 & 88 & 88.00 \\
\hline Teacher-29 & 4 & 5 & 5 & 4 & 4 & 5 & 4 & 4 & 4 & 5 & 5 & 4 & 4 & 5 & 5 & 5 & 4 & 4 & 4 & 5 & 89 & 89.00 \\
\hline Teacher-30 & 5 & 5 & 4 & 5 & 4 & 5 & 4 & 5 & 4 & 4 & 5 & 5 & 5 & 4 & 4 & 5 & 4 & 5 & 5 & 4 & 91 & 91.00 \\
\hline
\end{tabular}

Besides the results of the initial trial in the form of quantitative data shown in Table 3, it was also obtained some suggestions given by the respondents as qualitative data that became input in making improvements to blended learning design. The suggestions given by the respondents can be seen in Table 4 . 
Table 4

Suggestions from Respondents while Initial Trial

\begin{tabular}{|c|c|}
\hline Respondents & Suggestions \\
\hline Expert-1 & Please add facilities to upload material in the form of videos \\
\hline Expert-2 & Please add facilities to open an online learning schedule/agenda \\
\hline Expert-3 & Please add facilities to create questions in the form of multiple choice and essay \\
\hline Expert-4 & $\begin{array}{l}\text { Please add facilities to provide information about the completeness value of each } \\
\text { assignment has given }\end{array}$ \\
\hline Teacher-8 & $\begin{array}{l}\text { Make multiple choice questions and essays for each material, so can measure the } \\
\text { students' abilities in their affective, cognitive and psychomotor domains }\end{array}$ \\
\hline Teacher-12 & $\begin{array}{l}\text { Show the online learning schedules, so students are better prepared and appropriate } \\
\text { in the learning process using blended learning }\end{array}$ \\
\hline Teacher-18 & Add video or animation material \\
\hline Teacher-20 & Add the material URL, if the material is taken from an internet source \\
\hline Teacher-24 & $\begin{array}{l}\text { Add a profile picture of each student/teacher as a blended learning user, so that the } \\
\text { user's identity can be fully understood }\end{array}$ \\
\hline Teacher-28 & $\begin{array}{l}\text { Make an announcement of the online learning schedule clearly and surely, so that all } \\
\text { students can attend online learning according to the time set }\end{array}$ \\
\hline
\end{tabular}

e) Results at the initial trial revision stage

At this stage, several revisions were made to follow up on the suggestions given by some respondents when carrying out the initial trial. The revisions made fully can be shown in Figure 4 to Figure 9.

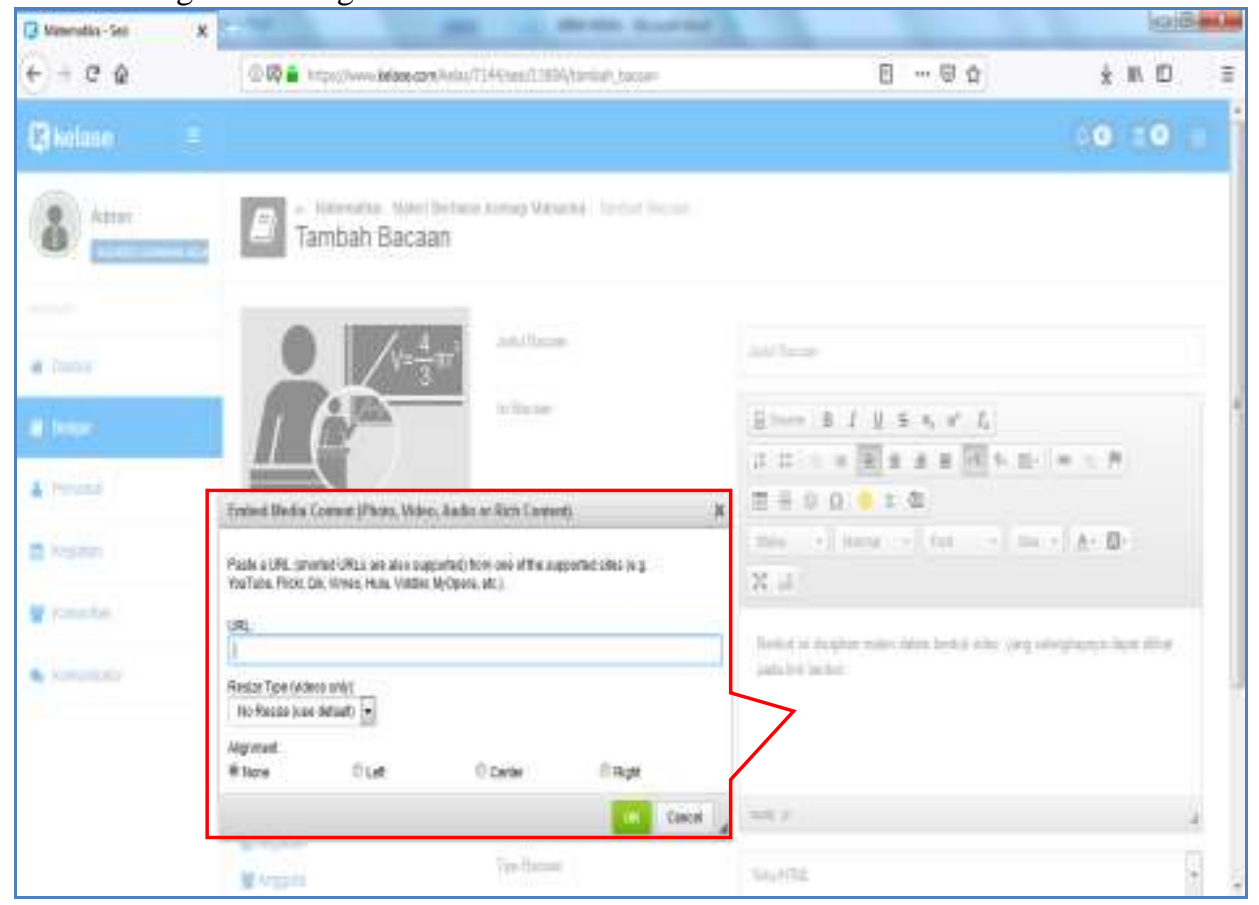

Figure 4

Display of Facilities to Upload Material in the Form of Video or Animation

International Journal of Instruction, July $2020 \bullet$ Vol.13, No.3 


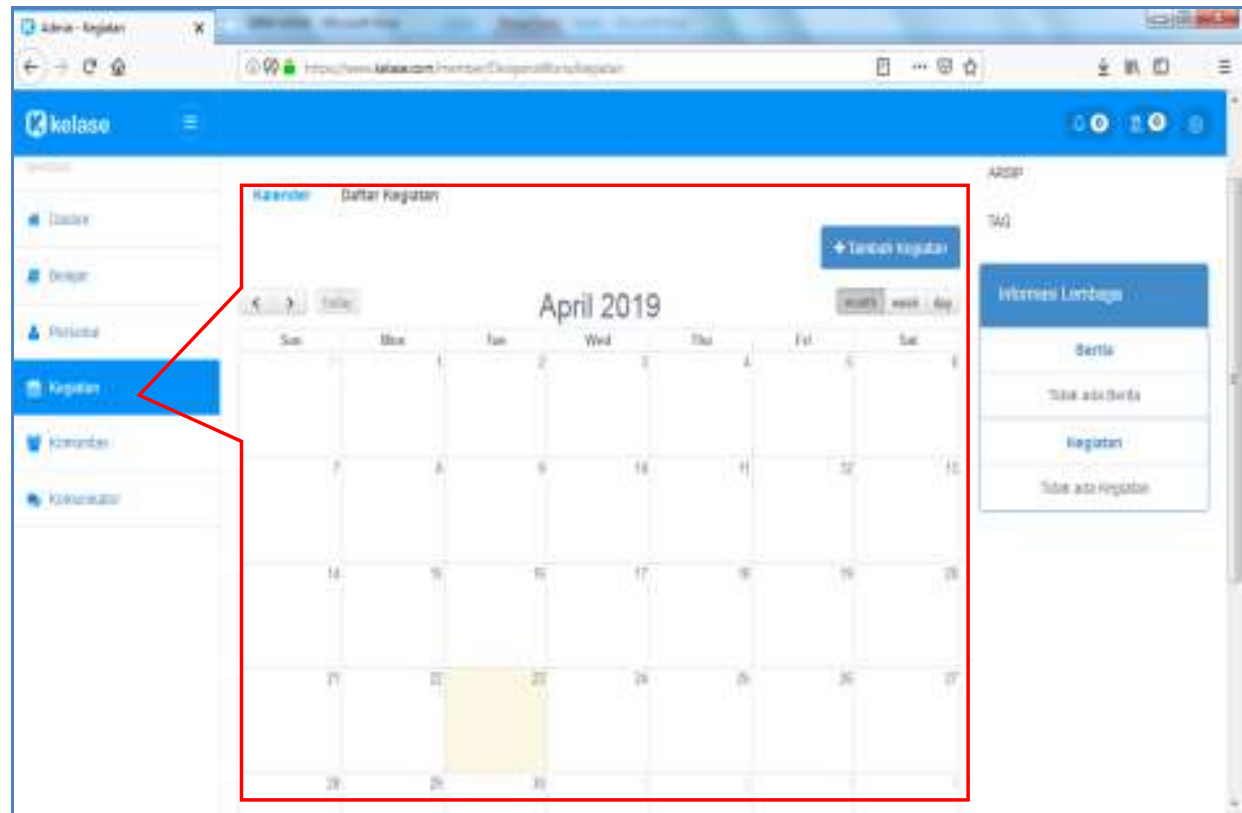

Figure 5

Facilities to Display the Schedule/Agenda for the Implementation of Online Learning

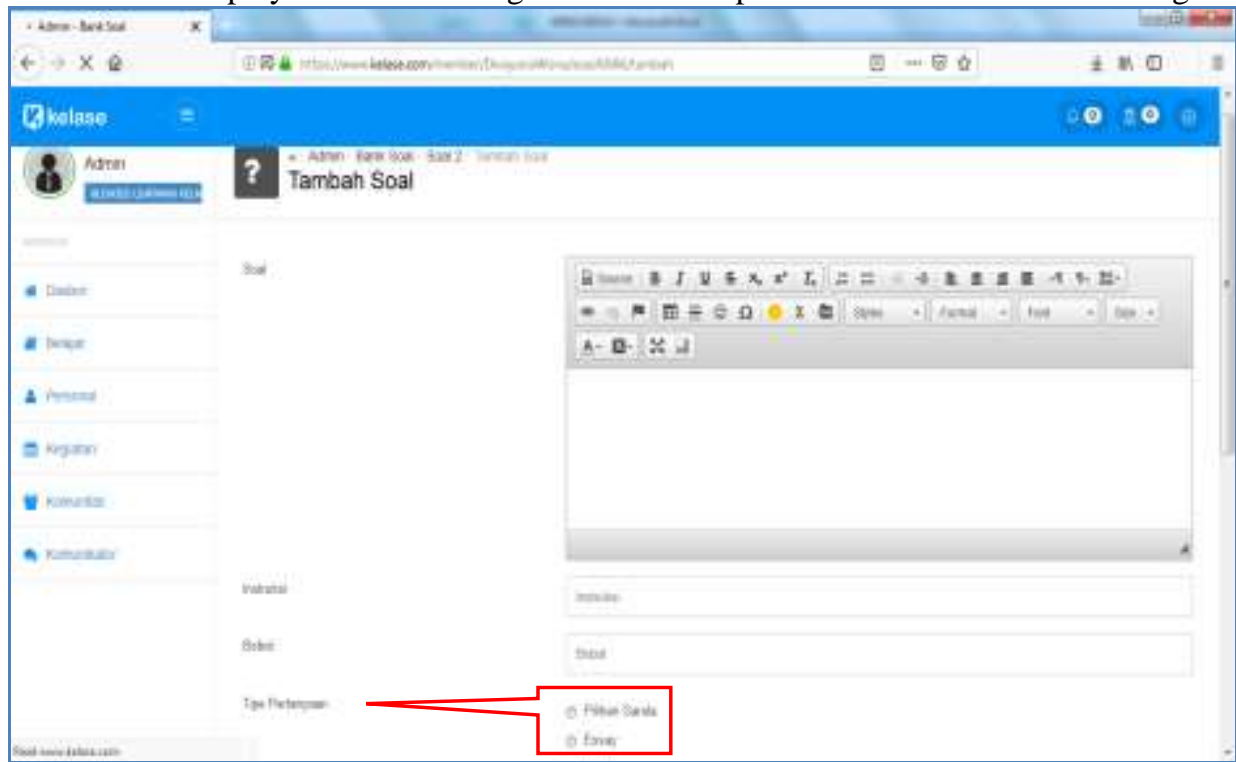

Figure 6

Display of Facilities to Make the Banks of Multiple Choice Questions and Essay Questions 


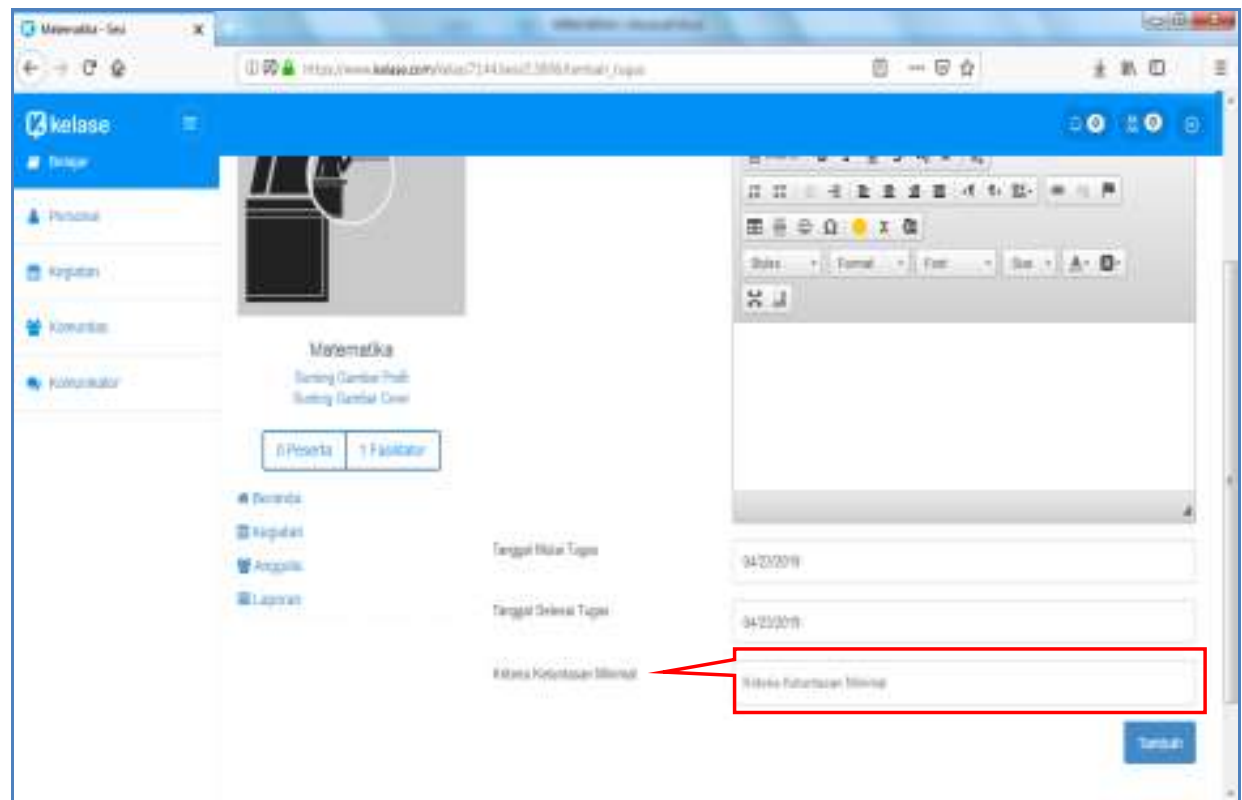

Figure 7

Display of Facilities to Determine the Completion Value of Each Assignment

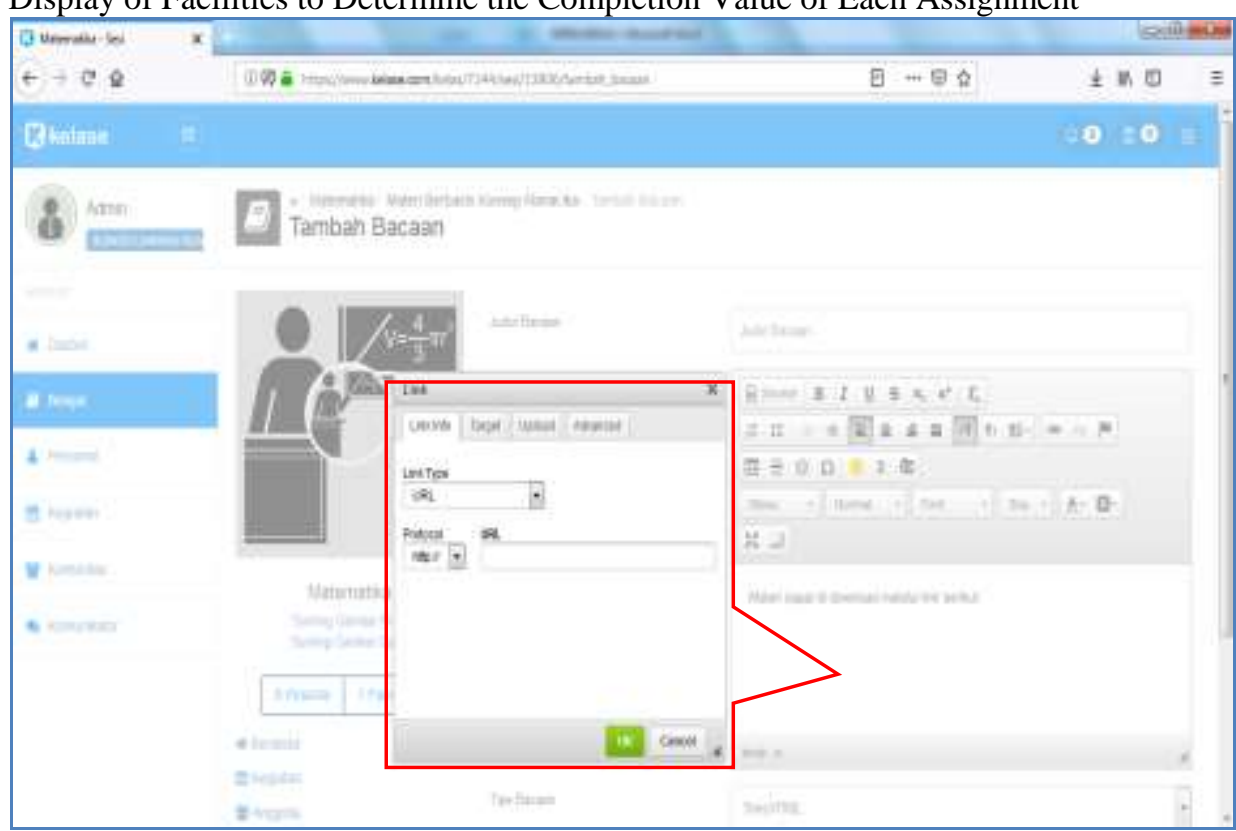

Figure 8

Display of Facilities to Add URL of Material Taken From Internet Sources

International Journal of Instruction, July $2020 \bullet$ Vol.13, No.3 


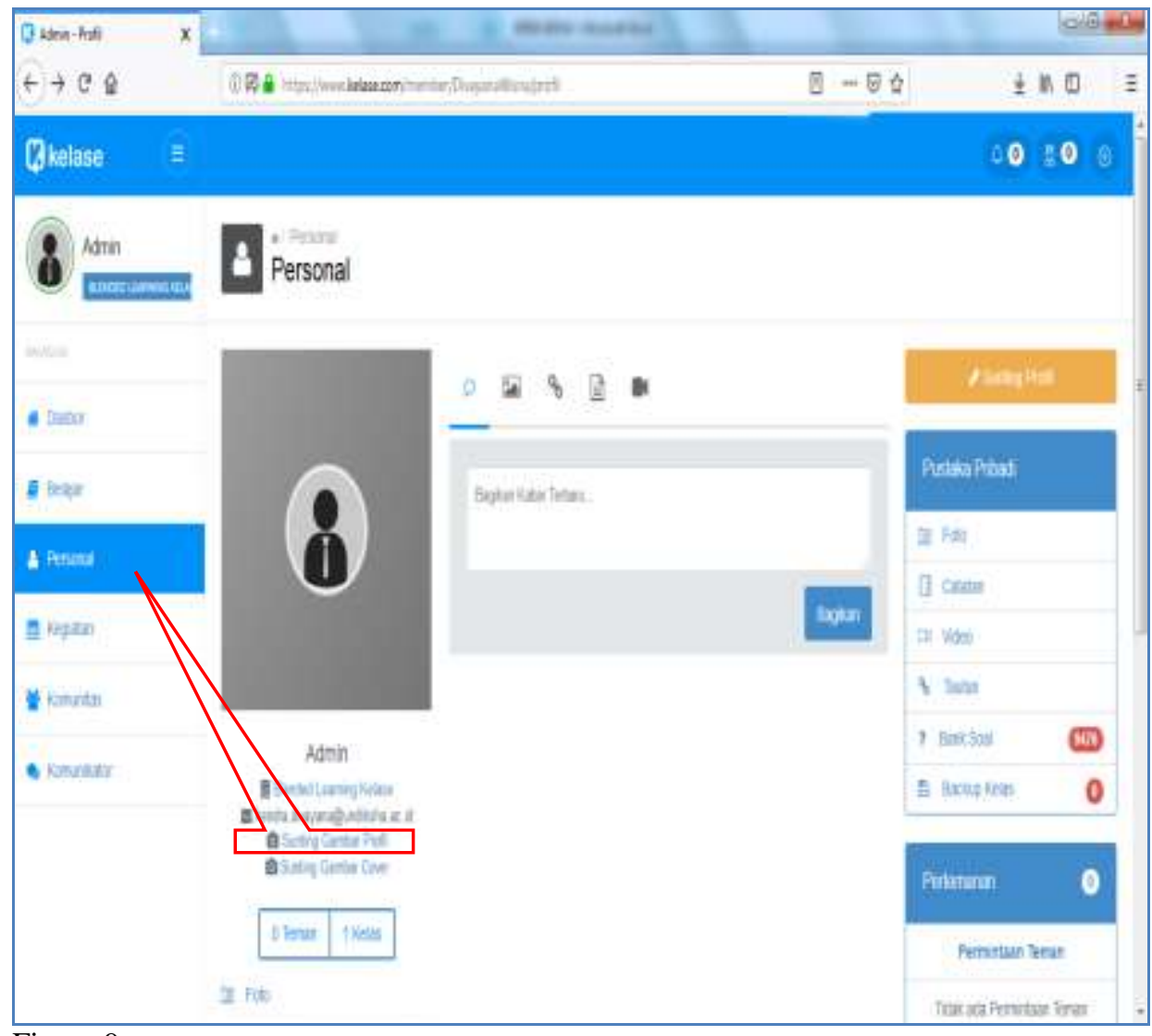

Figure 9

Display of Facilities to Change User Profile Photos

The results data obtained at the research stage and field data collection was used as the basis for making material content and blended learning containers that internalize Tri Kaya Parisudha's concepts. The content of Mathematics material for class X to class $\mathrm{XII}$ at the high school/vocational level is arranged in stages by adopting the concept of Superitem, so that students can hone their cognitive abilities ranging from the lowest difficulty level to the highest difficulty level. Tri Kaya Parisudha's concept consists of three components, including Manacika, Wacika, and Kayika (Divayana, 2018: 6). The Manacika component (good thinking) is implemented through a Manacika-based material form on the Kelase platform so that it can be used to determine student learning outcomes in the cognitive domain. The Wacika component (speaking well) is implemented through the Wacika-based material form on the Kelase platform so that it can be used to determine student learning outcomes in its affective domain. Kayika component (good action) is implemented through the Kayika-based material form on the 
Kelase platform so that it can be used to find out student learning outcomes in the psychomotor domain.

The data shown on Table 2 explains that the time needed starts from determining the material content to the making of blended learning design for 11 days. The number of personnel involved in the activity was three people with expertise in Mathematics education, informatics engineering education, and educational evaluation. Figure 3 shows the blended learning design made using the Kelase platform. The Kelase platform can be freely accessed from the internet through the URL: https://kelase.com/. In the Kelase platform equipped with facilities that allow the Mathematics learning process to be carried out with packaging based on Tri Kaya Parisudha concept so that learning outcomes can measure students' cognitive, affective and psychomotor domains. The material content of Mathematics presented in blended learning is taken from the Mathematics book class X to class XII, which is in accordance with the 2013 curriculum applicable in Indonesia. The content taken from the book then rearranged in stages from a simple level to the most complicated level by adopting the concept of Superitem so that it can improve students' critical thinking skills.

The results of the initial trial on the blended learning design that was presented on Table 3 show an average effectiveness percentage was $88.76 \%$ so that the blended learning design was good categorized. This occurs because the average effectiveness of blended learning was in the range of $80-89 \%$ when viewed from the five scale categorization standard shown on Table 1. The initial trial of the blended learning design was carried out by four experts and 30 Mathematics teachers. The instrument used to carry out the initial trial consisted of 20 items. In general, there are a number of suggestions given by respondents when conducting trials, such as (a) the need for material upload facilities in the form of videos, animations, URLs, (b) the need for online classroom learning notification facilities, (c) the need for question bank, (d) necessary facilities for completing value for each assignment, and (e) necessary facilities for update user profile photos.

Figure 4 shows the revised blended learning design related to the suggestions from respondents to add facilities to the blended learning so that users can upload video/animation material into the learning class. The material in the form of video/animation can be searched through the internet; then the URL is stored in the container available in Kelase. Video material can also be made by yourself; then a URL is made and stored in a container available at Kelase. The part in the red block in Figure 4 shows the container to place the URL that was created. Figure 5 shows the results of the revision related to suggestions for adding facilities to the schedule for implementing learning. The learning schedule can be set via the "activity" menu on the Kelase platform which is automatically equipped with a calendar so that it is easy to determine the day, date, and month of each learning activity. The part in the red block in Figure 5 shows the container for setting the activity schedule. Figure 6 shows the revised blended learning design related to respondents' suggestions for adding facilities that make it easy to make essays and multiple choices questions on the Kelase platform. Making multiple choice questions or essays can be done through the question bank menu in the 
admin section. On the question bank menu, there will be facilities to choose the type of question (either multiple choice or essay). The part in the red block in Figure 6 shows the types of questions that users can choose. Figure 7 shows the revised results related to respondents' suggestions to add facilities to determine the minimum completeness value in each task given to students. Making minimum completeness criteria in evaluating student assignments can be done by entering a minimum standard of value through the textbox facility in the "Minimum Completion Criteria" available in the activity of making assignments in the learning class. The section in the red block in Figure 7 shows the place to enter the minimum completeness criteria that must be achieved by students in answering the assignment given.

Figure 8 shows the revised results related to respondents' suggestions for adding facilities used in inserting material URL in the form of weblogs or websites sourced from the internet. The way to insert the URL can be done through the "link" menu available on the Kelase platform in the "add reading" section of the learning class. The section in the red block in Figure 8 shows where to enter the website/weblog material URL. Figure 9 shows the revised results related to respondents' suggestions for adding facilities that can be used to change the photo of a blended learning user profile. How to change profile photos can be done in the "edit profile picture" section available on the "personal" menu in the Kelase folder. The section in the red block in Figure 9 shows where to change profile photos.

In general, this research was able to present innovation to solve the constraints found in the studies previously carried out by other researchers. The results of this study had been able to be an answer to the limitations of Suanthara's research in 2018 that was related to the achievement of optimal learning outcomes in the cognitive, affective, and psychomotor domains. The solution that had been provided through the results of this study was to show the existence of material content that adopts the values of the Tri Kaya Parisudha concept (Manacika, Wacika, and Kayika) that used in the learning process. The concept of Manacika is used to measure cognitive domains because this concept is related to the management of logical thinking. The concept of Wacika is used to measure the affective domain because this concept is related to speech management, which directly impacts behavior. The Kayika concept is used to measure the psychomotor domain because this concept is related to time management and discipline, which directly impacts on performance.

The results of this study had been able to answer the limitation of Eryilmaz's research in 2015 related to the absence of complete material content with examples of exercise questions ranging from the easiest to the most difficult levels. The solution that had been provided through the results of this study was to adopt the concept of the superitem in the preparation of material and examples of exercise questions used in blended learning.

Similar to the limitation of Suanthara's research, the limitation of Jamil's study in 2018 in principle was also related to the lack of measurement of the affective, cognitive, and psychomotor aspects of students in solving cases/problems in the learning process. The solution that had been provided through the results of this study was to package the

International Journal of Instruction, July $2020 \bullet$ Vol.13, No.3 
material and test questions based on Tri Kaya Parisudha so that all domains of learning outcomes (affective, cognitive, and psychomotor) can be adequately achieved.

The results of this study were also able to be an answer to the research limitation of Supandi, Kusumaningsih, and Ariyanto that was conducted in 2014 related to the lack of a complete explanation of the triggering elements to improve students' affective abilities in learning through blended learning in Mathematics. The solution that had been provided through the results of this study was by preparing material and discussion forums that adopt the concept of Wacika in the Tri Kaya Parisudha teachings, to be able to measure student attitudes appropriately in following the learning process through blended learning.

Although this research has similarities with the research was conducted by Wijanayu, Hardyanto, and Isnaeni in 2018 in utilizing a free platform sourced from the internet to support the realization of the blended learning model, but of course, there are differences. The difference lies in the type of application that was used, wherein this study using a free application called Kelase, while in the research of Wijanayu, Hardyanto, and Isnaeni used a free application called Quipper School.

The constraint that was found in the research of Suana et al. in 2017 about the inconsistency of students in following discussion forums available on the Schoology platform had been answered through this research by providing attract discussions to students through the community forum facilities available on the Kelase platform. The research obstacle of Jubhari et al. in 2016, related to the low ability of students to express their ideas directly, had been answered through this research by providing discussion and community facilities in blended learning. The constraint of Permatasari's research in 2014 related to the limitation in measuring the affective domain in the Mathematics learning process, had been answered through this research by presenting discussion facilities and community forums in blended learning to measure the level of student activity in conducting discussions as evidence of affective domain measurement.

The limitation of Albiladi and Alshareef's research in 2019 about the unstructured content of English material in blended learning ranging from the lowest complexity to the highest level, had been answered through this research. The solution was provided from this research results was to use the concept of the superitem in creating structured material content ranging from the lowest to the highest difficulty level. The limitation of Utami, Santyasa, and Suswandi's research that was conducted in 2018 related to the lack of detail information about the mechanism of affective domain measurement in physics learning using blended learning, had been answered through this research. The solution was provided from the results of this study was to insert the concept of Wacika into the forum and discussion facilities that were contained in blended learning.

Proportion percentage of learning completeness measurement for cognitive, affective, and psychomotor domains in blended learning based on Tri Kaya Parisudha that was made using the Kelase platform in realizing hybrid-super item learning in mathematics subject refers to the average percentage of cognitive aspects on student book of the 2013 curriculum, especially for Mathematics subjects. The proportion percentage in the 
cognitive domain was $68.01 \%$, the affective domain was $23.67 \%$, and the psychomotor domain was $1.45 \%$. This is reinforced from the research results in 2015 that was conducted by Rufiana (2015: 20) which showed the average percentage of cognitive domain that was measured through the understanding aspect was $68.01 \%$, the average percentage of affective domain that was measured through the presentation aspect was $23,67 \%$ and the average percentage of psychomotor domain that was measured through the verification aspect was $1.45 \%$.

The presence of this study is able to provide a solution to overcome those obstacles of the previous research by inserting Tri Kaya Parisudha concept in blended learning so that the cognitive domain can be measured through the existence of Manacika-based material forms, affective domains can be measured through the existence of Wacikabased material forms, and psychomotor can be measured through the existence of Kayika-based material forms.

However, this research is also imperfect because there are still some obstacles, including: (1) the Superitem-based test instruments used to test cognitive, affective, and psychomotor abilities have not yet been tested for item validity and item reliability; and (2) the material content in the blended learning discussion is still not complex because it only refers to one source of books given at each level of high school education starting from class X to class XII.

\section{CONCLUSION}

The finding in this study was the blended learning design based on Tri Kaya Parisudha that made using the Kelase platform had been able to properly demonstrate the adoption of Superitem concept in packaging Mathematics material content in stages from a simple level to the most complex level. This was evidenced by the effectiveness level percentage of the design was $88.76 \%$, so included in the good category. The presence of the blended learning design has positive implications for student learning outcomes in the cognitive, affective, and psychomotor domains that can be optimally measured. Future work that can be done as a problem solving solution in this research is testing of validity and reliability the test instruments that adopt the Superitem-concept so that the instrument can accurately use to measure students' cognitive, affective, and psychomotor abilities in Mathematics learning using the Tri Kaya Parisudha-based blended learning. Besides, looking for additional other literature as a source of knowledge that is included as material content into blended learning, so that it can add insight and students' critical thinking skills in solving the complicated and complex cases in Mathematics learning.

\section{ACKNOWLEDGMENTS}

The researchers would like to thank the General Director of Higher Education of the Republic of Indonesia who had funded this research with proof of research contract number 128/UN48.16/LT/2019, so that this research can be carried out. Besides, the researchers also expressed the most profound gratitude to all those who helped in completing this research. 


\section{REFERENCES}

Albiladi, W.S., \& Alshareef, K.K. (2019). Blended learning in English teaching and learning: a review of the current literature. Journal of Language Teaching and Research, 10(2), 232-238.

Aminudin, M, Nusantara, T., Parta, I. N., Rahardjo, S., As'ari, A. R., \& Subanji. (2019). Engaging problems on trigonometry: why were student hard to think critically? IOP Conf. Series: Journal of Physics: Conf. Series, 1188, 1-10

Ariawan, I. P. W., Simatupang, W., Ishak, A. M., Agung, A. A. G., Suratmin, Adiarta, A., \& Divayana, D. G. H. (2018). Development of ANEKA evaluation model based on topsis in searching the dominant aspects of computer learning quality determinants. Journal of Theoretical and Applied Information Technology, 96(19), 6580-6596.

Divayana, D.G.H. (2018). Development of ANEKA-weighted product evaluation model based on Tri Kaya Parisudha in computer learning on vocational school. Cogent Engineering, 5, 1-33.

Ersoy, E. (2016). Problem solving and its teaching in mathematics. The Online Journal of New Horizons in Education, 6(2), 79-87.

Eryilmaz, M. (2015). The effectiveness of blended learning environments. Contemporary Issues in Education Research, 8(4), 251-256.

Hendikawati, P., Zahid, M. Z., \& Arifudin, R. (2019). Android-based computer assisted instruction development as a learning resource for supporting self-regulated learning. International Journal of Instruction, 12(3), 389-404.

Jamil, A.F. (2018). Development of student's worksheet to analyze student's algebraic thinking based on solo taxonomy. Advances in Social Science, Education and Humanities Research (ASSEHR), 160, 119-122.

Jubhari, R., Bazergan, E., Mokoginta, K., Sitoto, S., Syarif, B.P., \& Iswari, E. (2016). Makassarese and Buginese local wisdoms in SCL-based writing class (a case study). A Journal of Culture, English Language, Teaching \& Literature, 16(1), 91-117.

Permatasari, B. I. (2014). The effectiveness of the application of superitem in improving the understanding of mathematical concepts of class X SMAN 11 Makassar. Jurnal Matematika dan Pembelajaran, 2(1), 136-154.

Rufiana, I. S. (2015). Questions' cognitive level in mathematics' textbook of curriculum's 2013 of class VII for the middle education. Jurnal Dimensi Pendidikan dan Pembelajaran, 3(2), 13-22.

Suana, W., Maharta, N., Nyeneng, I. D. P., \& Wahyuni, S. (2017). Design and implementation of schoology-based blended learning media for basic physics I course. Jurnal Pendidikan IPA Indonesia, 6(1), 170-178.

Suanthara, I. N. D. E. (2018). The influence of Tri Kaya Parisudha learning model on the learning achievement of $\mathrm{V}$ semester students of the Hinduism education department 
at STKIP Agama Hindu Singaraja in the academic year 2016/2017. Jurnal Pasupati, $5(2), 136-152$.

Supandi, Kusumaningsih, W., \& Ariyanto, L. (2014, November). Blended learning design for mathematics in schools. Paper presented at International Seminar on Innovation in Mathematics and Mathematics Education $I^{\text {st }}$ ISIM-MED 2014, "Innovation and Technology for Mathematics and Mathematics Education", Department of Mathematics Education, Yogyakarta State University, Yogyakarta, 4954 .

Suyasa, P. W. A., Kurniawan, P. S., Ariawan, I. P. W., Sugandini, W., Adnyawati, N. D. M. S., Budhyani, I. D. A. M., \& Divayana, D. G. H. (2018). Empowerment of CSEUCLA model based on Glickman quadrant aided by visual application to evaluate the blended learning program on SMA Negeri 1 Ubud. Journal of Theoretical and Applied Information Technology, 96(18), 6203-6219.

Utami, N. P. N. N., Santyasa, I. W., \& Suswandi, I. (2018). The influence of blended learning model based on problems of physical learning achievements by students of class X Science in SMA 6 Denpasar academic year 2017/2018. Indonesian Review of Physics, 1(1), 1-6.

Wichian, D., \& Thanongsak, S. (2019). Efficiency and effectiveness of blended learning for critical thinking development in Thai vocational students. Revista Espacios, 4O(19), $12-21$.

Wijanayu, A., Hardyanto, W., \& Isnaeni, W. (2018). Blended learning method based on quipper school to improve concepts understanding and independence learning students. Journal of Primary Education, 7(1), 88-95. 